ARTICLE

DOI: $10.1057 /$ s41599-018-0152-2

\title{
Pharming animals: a global history of antibiotics in food production (1935-2017)
}

\author{
Claas Kirchhelle ${ }^{1}$
}

\begin{abstract}
Since their advent during the 1930s, antibiotics have not only had a dramatic impact on human medicine, but also on food production. On farms, whaling and fishing fleets as well as in processing plants and aquaculture operations, antibiotics were used to treat and prevent disease, increase feed conversion, and preserve food. Their rapid diffusion into nearly all areas of food production and processing was initially viewed as a story of progress on both sides of the Iron Curtain. However, from the mid-1950s onwards, agricultural antibiotic use also triggered increasing conflicts about drug residues and antimicrobial resistance (AMR). Significantly, antibiotic concerns did not develop evenly but instead gave rise to an international patchwork of different regulatory approaches. During a time of growing concerns about AMR and a post-antibiotic age, this article reconstructs the origins, global proliferation, and international regulation of agricultural antibiotics. It argues that policymakers need to remember the long history of regulatory failures that has resulted in current antibiotic infrastructures. For effective international stewardship to develop, it is necessary to address the economic dependencies, deep-rooted notions of development, and fragmented cultural understandings of risk, which all contribute to drive global antibiotic consumption and AMR.
\end{abstract}

\footnotetext{
${ }^{1}$ University of Oxford, Oxford, UK. Correspondence and requests for materials should be addressed to C.K. (email: claas.kirchhelle@wuhmo.ox.ac.uk)
} 


\section{Introduction}

n 2013, Britain's Chief Medical Officer Dame Sally Davies triggered what has amounted to half a decade of increasingly dire warnings about antibiotic overuse and antimicrobial resistance (AMR). Davies publicly likened AMR to a "ticking time bomb" (Walsh, 2013) and lobbied to include AMR in the UK's National Risk Register of Civil Emergencies as a threat comparable to major coastal flooding or a catastrophic terrorist attack (Sample, 2013). Davies' warnings were followed by a flood of expert reports, national action plans, and pledges to reduce antibiotic use by members of the World Health Organisation (WHO), the Farm and Agricultural Organisation (FAO), and the G20 (WHO, 2015; FAO, 2016; G20, 2017). In addition to subsidising antibiotic research and tackling human overuse, most actors have also committed to reducing antibiotic consumption in food production.

Achieving these reductions will not be easy. Globally, agricultural antibiotic use likely exceeds human consumption (Van Boeckel et al., 2015). Meanwhile, routine antibiotic use to treat and prevent disease, increase feed efficacy, and substitute labour previously devoted to the care of individual animals has acquired an infrastructural importance for many food supply chains. This antibiotic infrastructure is destined to undermine itself. Although agriculture's overall contribution to AMR remains contested, new metagenomics research and cases like the recent global spread of colistin resistance from Chinese pigs are clarifying the true threat posed by agricultural AMR selection (Liu et al., 2015; Tran-Dien et al., 2017).

However, so far, knowledge of the threat posed by AMR has failed to translate into effective international plans for antibiotic reductions. Recent projections predict that growing meat consumption in middle- and low-income countries will lead to a $69 \%$ increase of global agricultural antibiotic use between 2010 and 2030 (Van Boeckel et al., 2015). The situation is hardly better in high-income countries. Although decades of increasing use have recently plateaued or declined in the US and some European countries, overall consumption remains high, many producers remain dependent on routine antibiotic use, and antibioticintensive productions systems are still being exported to other parts of the world (FDA, 2017; VARSS, 2017). While everybody agrees that something has to be done, a robust way of tackling global non-human antibiotic use has yet to emerge.

Looking back at the past eight decades of agricultural antibiotic use, this paper argues that the lack of effective international reform should not surprise us. What emerges from the archives is not a story of simple political or economic choices but a story of antibiotic proliferation that is intimately connected to the industrialisation and integration of global agricultural production as well as to Cold War promises of development and prosperity. On both sides of the Iron Curtain, the twentieth century saw more people eat more meat than ever before. Whereas average per capita global meat consumption totalled $24 \mathrm{~kg}$ in 1961, it totalled $43 \mathrm{~kg}$ in 2014. Although significant disparities remain between high- and low-income countries, meat consumption rose faster than global population growth. Unsurprisingly, rising demand has entailed substantial changes of global animal production, which grew 4-5-fold since 1961 (Ritchie and Roser, 2018). Although the beginnings of agricultural intensification, large confinement operations, and integrated supply chains predate the 1940s (Fitzgerald, 2003; Saraiva, 2016), rising meat consumption and the farm as factory became powerful symbols of Cold War competition. By the 1960s, industrialised animal production had emerged as an important export of both capitalist and non-capitalist systems to allies and non-aligned countries alike. Antibiotics' role in this story of systems proliferation was initially that of a universal lubricant to control disease pressure, increase yields, reduce labour costs, and contain economic risks for producers. However, with farm sizes and productivity rising rapidly, their lubricant function was soon seen as essential for the smooth running of food production. Facilitated by rising meat consumption, ideological rivalry, and genuine market demand, the system of intensive and antibiotic-dependent high volume livestock production took on global dimensions.

The ensuing global spread of 'antibiotic infrastructures' (Chandler et al., 2016) in agriculture does not mean that they developed identically. Although the same substances were employed in the Midwest, Yugoslavia, and Japan, national and regional patterns of use could vary substantially. A similar variation also characterised perceptions of risk. Experts had been warning about antibiotic hazards since the 1940s. While initial warnings were often ignored with reference to antibiotics' immediate benefits in the quest to improve agricultural productivity, the following decades saw rising international concern over residues and AMR proliferation. Significantly, different publics prioritised different risks. This variation of risk perceptions both between nations and between different social groups has been studied intensively by historians and sociologists and strongly impacted antibiotic use and policymaking (SmithHoward, 2010; Morris et al., 2016; Etienne et al., 2017; Hockenhull et al., 2017; Begemann et al., 2018): some countries decided to target antibiotic residues in food and milk, others decided to tackle agricultural AMR selection, and others decided to do nothing at all. Although it is beyond the scope of this paper to reconstruct national case studies in detail, varying risk perceptions, economic imperatives, and local patterns of use had given rise to a global patchwork of antibiotic regulations by the early 1970s. This regulatory patchwork fragmented further over the next three decades and proved unable to curb either antibiotic use or AMR. In the vast majority of countries, antibiotic regulation ultimately remained subject to a risk benefit matrix, which prioritised the fiat of cheap and reliable protein over more abstract considerations of antibiotic stewardship.

In many ways, current policymakers remain subject to the path dependencies and blind spots of the past 80 years of antibiotic use and regulation. Acknowledging our rootedness in these structures is a necessary first step to reforming them. While recent reports present AMR as a monolithic challenge to be solved via narrow reforms and national antibiotic reductions, this essay argues for more adaptable, multi-faceted, and long-term global reforms. For interventions to be successful beyond the nation state, they will have to take into account the complex cultural, political, and economic systems driving global antibiotic use on factory farms and backyard operations alike. Effective policies will also have to adapt quickly to constantly evolving AMR research and production systems. Finally, the story of regulatory failure featured in this essay also serves as a warning not to displace blame for drug overuse on middle- and low-income countries. Having pioneered and exported antibiotic-dependent production and consumption since the 1940s, high-income countries have a moral responsibility to contain the fallout of these systems in other parts of the world.

\section{Origins}

The history of agricultural antibiotics begins with the synthetic sulphonamides. In 1935, German pharmaceutical manufacturer Bayer marketed Prontosil (sulfochrysoidine). Prontosil was the first effective drug against Gram-positive infections and a commercial success (Lesch, 2007). By the end of the decade, Prontosil and other often closely related sulphonamides had ushered in a new era of chemotherapy. The drugs were also introduced to 
agriculture. In Britain, Prontosil and other sulphonamides like sulphapyridine were marketed for use in animals from 1938 onwards. ${ }^{1}$ What would eventually come to be termed biological antibiotics were also adopted rapidly. In 1940, gramicidin was used to treat a mass outbreak of mastitis (udder infection in cows) at New York's World Exhibition (Bud, 2009). The wartime importance of milk production also meant that precious penicillin supplies were tested against mastitis in both Britain and Denmark as early as 1943 (Woods, 2014; Cozzoli, 2014).

While the Second World War constrained European drug manufacturing, US companies like Merck, Pfizer, and American Cyanamid emerged as leading producers of synthetic and biological antibiotics. With strong interwar links connecting US pharmaceutical and feedstuff companies (Landecker, 2017), researchers also trialled the mass-medication of entire herds and flocks. Medicated feeds and water not only promised to curb disease in concentrated animal populations but also to raise productivity by reducing the expensive labour spent caring for individual animals. In 1948, Merck's sulfaquinoxaline was the first antibiotic to be officially licensed for routine inclusion in poultry feeds against coccidiosis. Antibiotic use also increased in other areas of US food production: sulphonamides were used against foulbrood in commercial bee hives; biological antibiotics curbed infections in farmed fish; and antibiotic tubes against mastitis proved popular in the dairy sector (Jones, 2003; Lesch, 2007; Campbell, 2008; Smith-Howard, 2017; Kirchhelle, 2019).

Nontherapeutic antibiotic use soon proved equally lucrative. Investigating antibiotic fermentation wastes as an alternative source of expensive vitamin $B_{12}$ feed supplements, researchers at American Cyanamid's Lederle Laboratories found that unextracted antibiotic residues were capable of increasing animals' weight gains. Feeding low-dosed antibiotic growth promoters (AGPs) was also believed to prophylactically protect against bacterial disease (Finlay, 2004; Bud, 2009; Finlay and Marcus, 2016). Following the announcement of the antibiotic growth effect in late 1949, Lederle sales boomed. Across the US, the new feeds were rapidly adopted by farmers eager to supply booming post-war demand for meat. According to AGP co-discoverer, Thomas Jukes, Lederle was soon selling "tankcars of brine containing residues from the fermentation" (Jukes, 1985). The new $\mathrm{B}_{12} / \mathrm{AGP}$ feeds proved particularly popular in the corn-rich Midwest and were officially licensed in 1951. On farms, the boundaries between growth promotion, therapy, and prophylaxis soon blurred. Meanwhile, industry scientists devised further nonhuman antibiotic applications as a lucrative source of revenue beyond the seemingly saturated human antibiotic market. By the mid-1950s, streptomycin sprays and solutions were used to treat and prevent bacterial plant infections while tetracycline preservatives delayed spoilage in US fish, shellfish, and poultry (Kirchhelle, 2019).

Promoted by manufactures and authorities like the US High Commission in West Germany, it did not take long for new antibiotic applications to cross the Atlantic (Cozzoli, 2014; Kirchhelle, 2016). Although European veterinarians were already using antibiotics to treat individual animals, the end of rationing, falling drug prices, and new AGPs led to a rapid expansion of overall antibiotic consumption. AGPs were licensed for use without veterinary prescription in West Germany in 1951, in Britain in 1953, in the Netherlands in $1954,{ }^{2}$ and in France in 1955 (Thoms, 2012, Kirchhelle, 2018). ${ }^{3}$ Most countries initially licensed penicillin, oxytetracycline, and chlortetracycline growth promoters. Probably due to its strong penicillin industry (Burns, 2005; Burns, 2011), the Netherlands only licensed tetracycline AGPs in 1959 (Witte, 2012; Manten et al., 1962). ${ }^{4}$ In Britain, a legal loophole also enabled the use of tylosin (Kirchhelle, 2018). In France, the three standard AGPs were soon joined by erythromycin and-on a smaller scale-by oleandomycin, spiramycin, neomycin, and framycetin. In West Germany, bacitracin, oleandomycin, taomycin, and flavomycin AGPs were also licensed (Manten, 1963; Tiews, 1970). In contrast to the US, farmers could usually only purchase premixed antibiotic solutions and feeds. West European veterinarians thus retained far greater control over antibiotics than their US colleagues, whose post-war loss of influence was exacerbated by farmers' easy antibiotic access (Jones, 2003; Smith-Howard, 2017).

Europeans' rapid licensing of AGPs was in part due to genuine agricultural demand and in part due to post-war policies designed to reduce feedstuff imports, free agricultural labour for industry, and increase livestock production and consumption. Uptake also varied between different livestock sectors. Medicated feeds were adopted rapidly in the poultry sector. Importing US breeds and confined housing systems, producers like Geoffrey Sykes in the UK, Heinz Lohmann (Wiesenhof) in West Germany, and CipZoo in Italy developed large-scale integrated production facilities. Similar to the US, rising animal concentrations were facilitated by routine antibiotic use (Thoms, 2012; Godley and Williams, 2009; Tessari and Godley, 2014). Pig and cattle producers were more selective. While areas with cheap grain access along the North Sea coast gradually adopted confined and more antibiotic-dependent forms of pig production during the 1960s, the smaller and varied structure of pig operations in other areas reduced antibiotic uptake. In Britain, mixed feed trials, popular outdoor systems, and the fishing industry's production of cheap alternative vitamin $\mathrm{B}_{12}$ disappointed initial projections of rapid AGP uptake (Woods, 2012; Kirchhelle, 2018). ${ }^{5}$ In the cattle sector, producers' frequent focus on dairy rather than meat production also made antibiotic additives less popular than in the US (Kirchhelle, 2019). Although there is thus not always a clear correlation between European intensification and antibiotic use, sinking drug prices and pressure for feed efficiency gradually overcame initial agricultural hesitancy. In 1958, it was estimated that up to $50 \%$ of British pigs were fed antibiotics and that nearly all unweaned piglets had access to food containing tetracyclines (Williams Smith, 1958). Eight years later, West Germany's Minister of Agriculture estimated that $80 \%$ of mixed feeds for young pigs, veal calves, and poultry contained antibiotic additives (Kirchhelle, 2016).

Similar to the US, antibiotics also entered other areas of European food production. Mostly streptomycin-based plant sprays and solutions were licensed from the mid-1950s onwards to combat American fire blight, a destructive bacterial disease of fruit trees and related plants, which had spread to Europe in 1957. After extensive trials, the British government also licensed antibiotic preservatives for fish in 1964 (Bundestag, 2008; Kirchhelle, 2018). Although antibiotic preservatives did not prove popular in continental Europe, Norway and Iceland trialled the use of antibiotics to preserve whale meat. In the whaling industry, bacterial spoilage and long processing times posed significant problems. Before a harpooned animal could be processed, it had to be pulled in and inflated with oxygen to stop it from sinkingwhich increased autolysis. Even after processing commenced, carcases cooled slowly. In order to increase whale meat and offal yields, whalers began to experiment with tetracyclines around 1950. Antibiotics were incorporated into explosive harpoons and injected into carcasses via inflation devices or aboard ships. The results were excellent: bacterial contamination and carcass swelling decreased while offal, meat, and oil quality increased. By 1953, the Icelandic whaling station at Hvalurfjördur started routinely using Pfizer's biostat (oxytetracycline). Norwegian and Soviet whalers soon followed suit (Tonnessen and Johnsen, 1982).

Therapeutic and nontherapeutic antibiotic use also spread to other US allies. Japan had launched its own antibiotic production trials during World War II. After 1945, US developmental aid and 
new factories led to antibiotic self-sufficiency within 3 years (Bud, 2009). Licensing antimicrobial feed additives from 1953 onwards (Morita, 1997), Japan soon experienced its own agricultural antibiotic boom. Although it established residue limits and banned antibiotic preservatives, expensive fodder imports, limited land availability, and productivity-oriented policies fostered increasingly antibiotic intensive forms of livestock and fish production from the 1960s onwards (Wesley, 1996; Morita, 1997). Antibiotics also acquired an important role in rice production. In 1958, Japanese researchers isolated the streptogramin antibiotic blasticidin S. Licensed for use against rice blast disease in 1961, blasticidin S. dusts and solutions were heralded as a safe substitute for mercury and arsenic-based products in the wake of contemporary organic mercury poisonings in the Minamata area. Further antibiotics like kasugamycin (licensed 1965), polyoxin (licensed 1967), and validamycin (licensed 1972) were also deployed against plant infections (Misato, 1976). Caught in a vicious cycle of AMR selection and higher-dosed treatment, Japan's annual use of blasticidin S., kasugamycin, polyoxin, validamycin, streptomycin, and chloramphenicol-based plant products totalled over 14,000 tonnes by 1974 (Misato et al., 1977).

Non-human antibiotic use was not confined to capitalist countries. During the 1940s, the Soviet Union (USSR) and China had also developed limited penicillin capabilities. However, production increased dramatically after 1945 when the US, Britain, and the United Nations Relief and Rehabilitation Agency (UNRRA) disseminated more advanced penicillin know-how. Expertise and non-commercial pilot plants were provided to Italy, Belarus, Ukraine, Poland, China, Czechoslovakia, and Yugoslavia (Bud, 2009). However, as a result of growing Cold War tensions, UNRRA was largely shut down in 1947 and Western exports curtailed. Antibiotic production and research subsequently emerged as a field of superpower rivalry and espionage (Krementsov, 2007; Cozzoli, 2014; Capocci, 2014). From the 1950s onwards, communist publications regularly celebrated the construction of new antibiotic plants, antibiotic aid to communist or non-aligned states, and new 'Soviet' antibiotics like albomycin (1951), furacillin (1955), and grisemin (1956/57) (Gause, 1955; Suskind, 1960). ${ }^{6}$ Communist antibiotic experts were also sent to Western countries as part of high-profile delegations.?

However, behind the scenes, the Soviet bloc struggled to maintain reliable drug supplies. Throughout the 1950s, Western diplomats and dissidents claimed that communist antibiotics were scarce and of poor quality. Those who could afford it preferred expensive Western imports. ${ }^{8}$ In 1955, the British legation to Budapest reported rumours about 'positively lethal' ${ }^{\text {' Hungar- }}$ ian penicillin exports to China. Although quality problems persisted, the overall supply situation gradually improved. In addition to penicillin and streptomycin, the USSR and Eastern European countries began to produce generic versions of illegally sourced proprietary Western tetracyclines from the mid-1950s onwards-albeit with names like tetran or biomycine. ${ }^{10}$

Agricultural antibiotic use also became more common. In 1955, experts at Moscow's Soviet Agricultural Exhibition proudly demonstrated antibiotic mastitis treatments to rather unimpressed British delegates. ${ }^{11}$ Attempting to ameliorate the effects of unpredictable harvests, Soviet planners were also interested in antibiotic preservatives and feed additives. ${ }^{12}$ From the late $1950 \mathrm{~s}$ onwards, countries throughout the Soviet bloc began constructing factories for antibiotic/ $\mathrm{B}_{12}$ supplements. Planners' shift towards AGPs coincided with a new emphasis on increasing living standards and meat consumption as well as freeing agricultural labour via industrialised food production. In 1959, Pravda announced that bottlenecks in livestock production would be overcome by integrating the fodder industry and feeding 'bone and fish meal, fodder dregs, antibiotics, biostimulators, acidophilous preparations, and vitamins'. ${ }^{13}$ In Bulgaria, construction of a new antibiotic plant began in Peshtera in 1959. The plant was supposed to annually produce 200 tons of 'Biovit-60' (containing 'biomycin'-probably chlor- or oxytetracycline-and vitamin $\mathrm{B}_{12}$ ), which would be sold in special fodder shops. Another chlortetracycline- $\mathrm{B}_{12}$ factory was constructed with the help of Soviet engineers in Iasi in Rumania in 1958 and further factories were planned in Czechoslovakia. ${ }^{14}$ In the East German Democratic Republic (GDR), the early 1950s had been marked by a crisis of drugs availability - in part caused by Soviet antibiotic requisitions for North Korea. ${ }^{15}$ However, by 1955, the GDR was producing its own penicillin, streptomycin, and chloramphenicol. Regular tetracycline production started with the help of modified Yugoslav cultures in the 1960s (Schramm, 2008). Although complete GDR self-sufficiency was only achieved around 1970 (Thoms, 2008), available drugs were used to treat conditions like mastitis from the mid-1950s onwards (Müller, 1999). AGPs were made available around 1959. Initially, penicillin and streptomycin were added to bone meal and other $\mathrm{B}_{12}$-rations. Tetracycline AGPs became available from ca. 1963 onwards (Nehring, 1959; Jeroch et al., 1978; Stock, 2014).

Agricultural antibiotic use not only spread in the northern hemisphere. Concerned about overpopulation and hunger-fuelled communism, American policymakers and researchers came to see the global export of yield-increasing technologies like antibiotics as a way of defending Western values (Cullather, 2010). US researchers also trialled antibiotic feeds to alleviate malnutrition in humans. In addition to 1950s trials in the US, low-dosed "aureomycin candy" was fed to malnourished children in Guatemala (Podolsky, 2017).

The systematic export of surpluses and yield-increasing technologies suited both US farmers as well as larger pharmaceutical and integrated feed manufacturers. Fostered by US developmental politics, US antibiotics and feeds were soon being fed to livestock in Africa, South America, and Southeast Asia where governments were keen to modernise agriculture in order to trigger a 'take-off of national economies. In 1961, Antonio Santos Ocampo Jr from Arenata University expressed concern about the rapid increase of Philippine antibiotic use. Promoted by 'Pfizer people', 'terramycin egg formula and the anti-germ 77 sells like hot cake. ${ }^{16}$ In South Africa, a dearth of veterinarians had led to the waiving of prescription requirements for many drugs in 1947 (Henton et al., 2011). Widely-advertised Anglo-American antibiotics soon proved popular on farms. A 1972 survey of large South African pig farms (producing ca. $10 \%$ of pigs slaughtered in 1970) found that ca. $80 \%$ of producers routinely fed antibiotic creep feeds-dietary supplements for young animals-to piglets for 2 to 3 weeks (Bakker and Davies, 1972). Other Western companies followed the example of US producers by building antibiotic plants abroad or by signing franchise agreements with local producers. ${ }^{17}$

By the 1960s, antibiotics were thus spreading rapidly throughout global food production. While reliable data from the Soviet bloc is difficult to obtain, the period between 1951 and 1970 saw total US antibiotic use increase over 11-fold from 690 to 7670 tonnes and non-medicinal antibiotic use (i.e., AGPs, sprays, etc.) increase over 30 -fold from 110 to 3310 tonnes (43.3\% of total use) (NAS, 1980). ${ }^{18}$ In France, ca. 30 tonnes were added to animal feed in 1964 (François, 1966). In Britain, experts estimated that ca. $41 \%$ (168 tonnes) of all antibiotics were consumed by animals in 1967-of which ca. 84 tonnes were feed additives (Swann, 1969). Commentators also noted that drug dosages in feed were steadily increasing (Weber, 1962). With farmers on both sides of the Iron Curtain under political and economic pressure to produce more animals more efficiently, easy access to antibiotics seemed necessary for further agricultural and societal development. 


\section{Fragmented concerns (1949-1970)}

Spreading antibiotic infrastructures initially elicited few concerns. During the 1940s and 1950s, the vast majority of US and Soviet commentators celebrated agricultural antibiotics as a sound way to enhance animal productivity and preserve food. When Soviet leader Nikita Khrushchev visited US farms in 1959, US commentators stressed the superior productivity of American farms and praised the widespread application of post-war technologies like antibiotics. ${ }^{19}$ According to Britain's Times, antibiotic preservatives were 'the greatest advance in the field of processing perishable foods since the advent of refrigeration'. ${ }^{20}$ Prevailing complacency changed only slowly in the face of growing concerns about antibiotic residues, antibiotics' alleged facilitation of animal welfare abuse, and agricultural AMR selection. Significantly, concerns evolved in a fragmented fashion. Heavily influenced by different cultural risk perceptions (risk epistemes) and economic priorities, regulatory frameworks diverged (Kirchhelle, 2019).

In the US and West Germany, public concerns and regulatory action tended to centre on antibiotic residues, rather than AMR. Following long-standing complaints by dairies about antibiotics' disruption of cheese production, consumers were shocked to learn that up to $10 \%$ of US milk samples were contaminated with penicillin during the mid-1950s. Residues occurred as a result of over-dosed mastitis treatments, farmers' noncompliance with withdrawal times, and illegal antibiotic sprinkling into milk to delay spoilage. The bulked collection of milk from multiple farms also meant that drug residues from one cow could now contaminate thousands of litres of milk. When problems persisted despite stricter rules by the US Food and Drugs Administration (FDA), antibiotics became culturally associated with other dangerous chemicals suspected of 'poisoning' Americans or causing cancer. Under intense pressure, the FDA introduced the first national monitoring programme for penicillin residues in milk in 1960 (Smith-Howard, 2010). Six years later, similar public concerns and new residue detections resulted in the first national monitoring programme for antibiotics in meat and license withdrawals for antibiotic preservatives (Kirchhelle, 2019).

In West Germany, antibiotic residues acquired a similar cultural status as dangerous chemistry ('Chemie'). Rooted in interwar concerns about adulteration, degenerative disease, and cancer, 1950s protest against chemical contaminants was fostered by prominent scientists like Nobel laureate Adolf Butenandt and pharmacologist Hermann Druckrey. Although the antibiotics involved were not carcinogenic, the prospect of US-style antibiotic food preservation evoked particularly strong public concerns about alleged invisible poisoning. In 1958, West Germany's new Food Law (Lebensmittelgesetz) explicitly banned antibiotic preservatives. Although officials managed to circumvent expensive residue monitoring by dubiously claiming that they were unaware of problems, ${ }^{21}$ public concerns persisted. After spot tests revealed considerable residues in German meat, the government eventually introduced a mass-monitoring programme in the mid1970s (Kirchhelle, 2016; Thoms, 2017).

Although they also established penicillin monitoring for milk in 1963, British regulators were far more concerned about agricultural AMR selection. This concern was in part due to the bacteriological surveillance capabilities of Britain's Public Health Laboratory Service (PHLS). In 1960, PHLS data on AMR proliferation in agricultural settings led to the creation of the socalled Netherthorpe Committee. Strongly influenced by power struggles between British veterinarians and farmers, the 1962 Netherthorpe Report endorsed existing antibiotic use but recommended restrictions of future antibiotics. This initial compromise came under fire in 1964 when Ruth Harrison's bestseller Animal Machines attacked alleged welfare abuses, drug overuse, and AMR selection on 'factory farms'. High-profile warnings about 'infectious AMR' by PHLS researcher Ephraim Saul ("Andy") Anderson enhanced public concerns about agricultural antibiotics. Building on 1950s Japanese research, Anderson highlighted that bacteria could 'communicate' AMR by exchanging small fragments of extrachromosomal DNA called plasmids. This 'infectious' mode of AMR proliferation also occurred between different bacteria species (horizontal resistance transfer) and was capable of conferring resistance against multiple antibiotics simultaneously.

Anderson's reports subverted existing risk models. Researchers had previously believed that certain bacteria were either inherently resistant to specific antibiotics or evolved new defence mechanisms via spontaneous mutations. Inherent or mutational resistance could then be passed on 'vertically' to subsequent generations. Vertical proliferation models made most experts think of AMR as a common phenomenon that could, however, be contained by: (1) curbing the spread of resistant bacteria via infection control; (2) reducing antibiotic selection pressure; (3) competitively inhibiting resistant strains with sensitive strains; (4) combining different antibiotics to reduce the chance of successful resistance mutations. Horizontal resistance proliferation undermined these control models by necessitating not only the organismal containment of bacteria but also the containment of mobile genetic elements. According to this ecological view of AMR, any form of routine antibiotic use greatly exacerbated the risk of AMR selection and genetic proliferation. Crucially, Anderson's data showed that the selection and transfer of multiple resistance had taken place on British farms. A multi-resistant S. typhimurium had subsequently caused severe food poisoning outbreaks. According to Anderson, medically relevant antibiotics had to be restricted before uncontrolled agricultural use allowed more dangerous pathogens like Salmonella enterica serovar Typhi (typhoid) to acquire multiple resistance (Kirchhelle, 2018).

Under intense public pressure, British officials commissioned a major antibiotic review in 1968. In November 1969, the so-called Swann Committee recommended a series of reforms of which the restriction of medically relevant antibiotics to veterinary prescription was the most significant (Bud, 2009; Swann, 1969). Although critics argued that agricultural antibiotic use had not been shown to harm health, precautionary restrictions of medically relevant AGPs like penicillin and the tetracyclines were subsequently adopted by Britain (1971), member states of the European Economic Community (1973-1976), and Switzerland (1973) (Lebek and Gubelmann, 1979; Castanon, 2007).

Outside of Western Europe, the adoption of AMR-oriented AGP bans was far from universal. Preoccupied with ensuring the purity of US food, FDA regulators tried to equate AMR and residue hazards in 1966 but failed to enact AGP restrictions (Finlay and Marcus, 2016; Kirchhelle, 2019). In the Soviet sphere, acknowledgements of antibiotic hazards did not lead to residue or AMR-oriented restrictions. The same was true in South Africa where veterinary warnings about drug overuse and the detection of antibiotic residues in ca. 5\% of Johannesburg's milk did not lead to substantial reform (Anon., 1959; Meara, 1959; Van Den Heewer and Giesecke 1967). In Japan, resistant plant pathogens led to rotating antibiotic use on fields but no wider revaluation of antibiotic use in livestock production (Misato et al., 1977).

While consumer concerns and moral panics had led to residue controls and precautionary antibiotic restrictions in individual countries, they were not widespread enough and of sufficient duration to trigger wider international reforms of agricultural antibiotic use or of antibiotic-dependent production systems. Once high-profile problems were perceived to have been fixed at the national level, public pressure usually evaporated. With no broader consensus on reform emerging, the increasingly kaleidoscopic nature of international regulations further diminished 
the prospect of sustained collective action against the growing global threat posed by AMR.

\section{Expansion}

In the absence of meaningful international agreement on AMR risks or on measures to reduce drug dependencies, global antibiotic consumption surged. Between 1970 and 1978, the amount of US antibiotics used for non-medicinal purposes (excluding sulphonamides) rose from 3310 to 5580 tonnes (NAS, 1980). Even countries with AGP restrictions in place experienced a further rise of antibiotic consumption. In Britain, a brief postSwann dip was followed by an increase in the use of nontherapeutic antibiotics and of prescribed higher-dosed penicillin and tetracyclines (Braude, 1978). In Spain, a 1984 study found that roughly half of antibiotics were being consumed by livestock despite similar AGP restrictions (Santesmases, 2018). Meanwhile, antibiotic infrastructures spread to new countries and food production sectors.

In the US, feedlot systems drove a significant increase of drug consumption. Midwest feedlots had fattened cattle ahead of slaughter since the nineteenth century. However, as a result of the fencing off of grazing lands and cheap grain and corn feeds, the systems spread to other states from the late 1950s onwards. By 1970 , nearly two-thirds of the US calf crop were placed in feedlots prior to slaughter. Feedlot conditions were conducive to antibiotic use. Since the 1950s, owners had used antibiotics to treat infections like footrot. By the mid-1960s, experts also recommended prophylactic antibiotic feeds to counteract production-related conditions like liver abscesses caused by high-grain diets or depressions of carcase quality caused by hormonal growth promoters. A decade later, cattle producers began to use new ionophore antibiotics like monensin (Coban/Rumensin-licensed in 1975) to prevent bloat and coccidiosis and to enhance animals' processing of high-roughage and grain diets. Within 10 years of monensin's licensing, ionophores were being fed to over $90 \%$ of US feedlot cattle (Dyer and O'Mary, 1977; Perry, 1980; Owens et al., 1991; Kirchhelle, 2019).

FDA regulators were powerless to stop proliferating antibiotic use. Reacting to EEC AGP restrictions, the agency launched three abortive attempts to restrict penicillin and tetracycline AGPs between 1970 and 1979. Calling for concrete proof of harm and employing counter science, pharmaceutical lobbyists successfully played on growing regulation wariness and concerns about 'stagflation' to defeat restrictions. With scientists appearing divided, Congress effectively imposed a moratorium on statutory AGP restrictions by calling for more research in 1979. Six years later, a National Resources Defence Council petition to ban AGPs suffered a similar fate (Finlay and Marcus, 2016; Kirchhelle, 2019).

Despite having restricted some AGPs, the situation was only marginally better in West Europe. While rising antibiotic use on farms was driven by economic pressure and easy drug access, it was also enabled by lacking political transparency and selfassessment. Once an antibiotic policy package had been enacted, officials were often missionary in their zeal to foster reforms' adoption abroad but lacklustre when it came to evaluating their own policies. In Britain, internal studies showed that partial AGP bans had failed to reduce AMR by the mid-1970s. However, the studies were embargoed and officials continued to preach the 'Swann gospel' of partial AGP bans abroad (Kirchhelle, 2018). A similar non-adjustment of AGP bans occurred in Switzerland (Lebek and Gubelmann, 1979). After being forced to establish national antibiotic residue monitoring, West German officials pressed for EEC-wide monitoring from 1973 onwards. However, officials reacted slowly to criticism of imprecise assay methods.
Similar to rhetoric in other countries, criticism of patchy domestic legislation was deflected with reference to alleged German leadership when it came to policing antibiotics and worse conditions abroad (Kirchhelle, 2016).

Meanwhile, EEC restrictions of US broadspectrum AGPS also suited European pharmaceutical manufacturers. Since the 1960s, companies like Bayer had used the spectre of AMR to promote allegedly safe nontherapeutic AGPs like virginiamycin.2 During the 1970s, officials were happy to aid pharmaceutical producers license new products and applications. West Germany's Ministry of Agriculture actively encouraged temporal exemptions from EEC feed directives to trial new additives like Hoffmann LaRoche's avoparcin or Hoechst's bambermycin (flavomycin) in cow fodder. Licensing decisions were made despite internal concerns about compromised hygiene in the case of flavomycin and flawed AMR testing protocols in the case of avoparcin AGPs (Castanon, 2007; Kirchhelle, 2016). ${ }^{23}$

European antibiotic use not only increased in livestock production but also in aquaculture and plant protection. Growing by over $8 \%$ p.a. from 1970 onwards (Culver and Castle, 2008), rearing systems for salmon and other species boomed along the North Sea coast with Scandinavia-particularly Norway-and Scotland emerging as hotspots. ${ }^{24}$ Problems with bacterial and fungal infections fostered routine use of antibiotics like oxytetracycline, amoxicillin, and sulfadimethoxine-ormetoprim (Romet 30). In addition to selecting for resistance in farmed fish, almost $80 \%$ of these antibiotics entered maritime environments where they selected for AMR in sediments and wild fish and shellfish populations (Munro, 1990; Samuelsen et al., 1992; Black, 2008; Capone et al., 1996). Meanwhile, spreading fire blight led to an expansion of antibiotic spraying and dusting in Belgian, Dutch, French, German, and Greek orchards (Backhaus and Klingauf, 1998). ${ }^{25}$

On both sides of the Atlantic, legal sales increases were paralleled by flourishing black and grey markets. From the 1960s onwards, officials warned about the unlicensed use of antibiotics like penicillin, erythromycin, and chloramphenicol. Often selling their wares at agricultural fairs or directly on farms, dubious merchants profited from divergent national regulations, some veterinarians' willingness to prescribe drugs for animals they had never seen, and farmers' interest in testing alleged performance boosters. In Germany, the word Autobahntierarzt (motorway veterinarian) emerged to characterise a person selling drugs out of the back of a car at service areas. The illegal merchandise was frequently of substandard quality and could lead to dangerous residues in animal tissues. Although exact numbers do not exist, the substantial scale of the European black market is attested by investigative journalism, prosecutions against black market retailers, and complaints logged by farmers about drugs' quality or by local veterinarians about illegal competition (Thoms, 2012; Kirchhelle, 2016; Thoms, 2017; Kirchhelle, 2019). In the US, a 1985 Congressional investigation found that "as many as 90 percent or more of the 20,000 to 30,000 new animal drugs estimated to be on the market" (Anon., 1985) had not been approved as safe and efficacious by the FDA.

Unsurprisingly, the public was not reassured by reports on AMR, residues, and illegal drug sales. During the 1970s and 1980s, a growing number of consumers turned to 'safe' organic food. Initially, consumers were served by an eclectic mix of young dropouts, old 'cranks', and artisanal producers-one of whose common denominators was that they reared animals without routine recourse to antibiotics or hormones. However, growing demand soon led to a professionalisation and upscaling of organic production. By the 1980s, supermarkets began stocking organic produce and producer associations established binding definitions of natural and organic farming (Belasco, 2007; Conford and 
Holden, 2011; Thoms, 2012; O'Sullivan, 2015). The organic movement was not exclusive to Europe or the US. Although sales were small by comparison, other high-income countries like Japan produced international bestsellers like Masanobu Fukuoka's Natural Farming, which explicitly rejected antibiotics and hormones in animal production (Fukuoka, 1985). Consumer concerns about chemical contaminants also pressured conventional producers to 'green' their rhetoric and reform rearing systems as well as chemical and pharmaceutical use. However, it would be wrong to speak of a wider agricultural paradigm shift: responsible for only a small fraction of overall food sales, organic farming offered a way for often wealthier consumers to opt out of conventional agriculture and a mode of antibiotic-intensive production that was still gathering steam (Mart, 2015; Kirchhelle, 2019).

In the Soviet sphere, purchasing organic was not an option. Instead, routine antibiotic use for growth promotion, therapy, and prophylaxis remained common. Fearful of fomenting political unrest by raising food prices and keen to maximise exports, officials were unwilling to rethink animal production. As a consequence, critical discussions of $\mathrm{AMR}$ and residue problems remained academic (Jeroch et al., 1974; Anon., 1981; Krüger, 2007). In East Germany, the 1970s saw antibiotic consumption skyrocket. Proud of the intensification of broiler production and increases of domestic meat consumption (Thoms, 2008), GDR officials decided to industrialise other livestock sectors. From 1968 onwards, GDR poultry, pigs, and cattle were moved into massive indoor facilities like the so-called pig high-rise (Schweinehochhaus) near Halle (Poutrus, 2002). Built as a symbol of communist efficiency with Soviet support between 1969 and 1970, the high-rise housed 500 sows and their offspring on three different floors. Piglets were transported offsite on elevators. Other facilities were similarly immense. In Neustadt an der Orla, GDR engineers constructed a 70-hectare facility for up to 185,000 pigs whose proximity to West Germany would generate lucrative exports. By 1990, the GDR had ten further similar-sized pig facilities, five 18,000-20,000 cattle production units, 112 milk facilities with over 2000 dairy cows each, and 35 laying units producing 200-295 million eggs p.a. (Laue, 2017).

Conditions in these facilities were often atrocious. In Neustadt, high ammoniac concentrations and feedstuff dust harmed farm workers while air- and waterborne emissions caused environmental damage throughout the region (Schönfelder, 2006). Inadequate animal welfare was compensated with liberal drug use. In addition to the mandatory inclusion of antibiotics into feeds, ${ }^{26}$ psychotherapeutic drugs like chlorpromazine, azaperon, and diazepam were used to reduce animal stress. Haphazard drug use increased residue and AMR problems-the latter problem was exacerbated by the GDR's status as a transit country for animal exports from other communist countries. ${ }^{27}$ Concerned about rejections of vital meat exports, the GDR introduced residue controls in 1976 and tightened controls for export animals in 1983 (Krüger, 2007; Stock, 2014; Laue, 2017). ${ }^{28}$

Supplying the pharmaceutical needs of the new livestock facilities proved difficult (Poutrus, 2002). With GDR drug production remaining unreliable, there were national shortages. In 2012, Hans-Joachim Hausmann remembered being called to a 1970 s meeting with the medical director of the district Sternberg. Attendees were informed that limited supplies of Depovernil (sulfamethoxypyridazine), a popular treatment for urinary tract infections, had been redirected to poultry production-one doctor proposed prescribing broilers instead (Hausmann, 2012). Trying to alleviate the shortages, GDR researchers trialled new alternative feed antibiotics like kormogrisin (grisin), paromycin, and lambdamycin. (Jeroch et al., 1974; Jeroch et al.; 1977, Jeroch et al., 1978). In 1980, nourseothricin feed antibiotics were developed at the GDR's Institute for Microbiology and Experimental Therapy to substitute the ca. 170 tonnes of oxytetracycline annually needed for AGPs. A close relative of kormogrisin, the streptogramin nourseothricin was subsequently mass-produced by the VEB Jenapharm and fed to GDR pigs and poultry from 1983 onwards (Schramm, 2008).

Nourseothricin's rollout provided a natural experiment for agricultural AMR selection. Between 1983 and 1990, GDR microbiologists traced previously non-existent transposon-encoded streptogramin resistance: first in E.coli from pigs, then in farm workers' gut flora, then in the gut flora of workers' family members, then in the gut flora of citizens in municipal communities, then in isolates from urinary tract infections, and finally in Salmonella and Shigella spp isolated from human diarrhoea cases (Hummel et al., 1986; Witte, 1999; Witte, 2000). Although their findings received international attention, they did not change GDR antibiotic policies or nourseothricin use. Following reunification in 1990, Germany successfully applied for a one year EEC exemption to exhaust remaining nourseothricin AGPs (Bundestag, 1990) and also trialled nourseothricin sprays against fire blight (Backhaus and Klingauf, 1998).

While nourseothricin AGPs were a response to growing economic problems within the communist bloc, rising affluence was simultaneously spreading and expanding antibiotic-dependent production systems in middle- and low-income countries. In Thailand, antibiotic-dependent intensification was driven by the Charoen Pokphand Group's (CPG) acquisition of US animal and pharmaceutical technologies around 1970 and subsequent integration of feed and animal production (Silbergeld, 2016). In South Africa, the introduction of limited restrictions and labelling changes for scheduled veterinary antibiotic products in 1965 failed to control consumption. Instead, overall use increased as a result of the parallel intensification of poultry, beef, and dairy production. Between 2002 and 2004, 1054 tonnes of antibiotics were sold as in-feed medications, 190.4 tonnes as water medications, and 269.8 tonnes as parenteral medications. Chloramphenicol and the nitrofurans were the only drugs banned for food animals (Eagar et al., 2012; Eagar and Naidoo, 2017). In Brazil, import substitution policies and booming grain and soy production fostered a similar increase of antibiotic intensive livestock rearing. Authorities actively welcomed foreign companies like Tyson Foods to turn crop surpluses into meat. Between 1968 and 1998, chicken production increased 20-fold and also became more intensive. By 2010, $90 \%$ of Brazilian poultry were produced in confined settings and the country is now the world's largest poultry producer (Silbergeld, 2016). Pig production also intensified. The effects on antibiotic consumption were predictable. By 2010, Brazil accounted for 9\% of global agricultural antibiotic use (Van Boeckel et al., 2015).

The expansion of antibiotic intensive animal production was even more dramatic in China. Since the 1950s, the Chinese had possessed Soviet-designed antibiotic plants and fed accruing mycelia wastes to animals (Shaohong, 1997). However, routine antibiotic use was not common on many farms until the 1980s. Following the death of Mao and the introduction of liberal economic policies, the government's strategy of inviting large US and Thai corporations rapidly increased the number of confined and integrated poultry operations. Although backyard production remained common, the Chinese pig sector also intensified. In 2004, a policy shift led to the Chinese acquisition of many foreign-owned facilities. Four years later, China was already producing almost eight times as many pigs as the US. In 2013, the Chinese Shunghui Group became the world's largest pig producer after acquiring the American Smithfield Foods Group (Silbergeld, 2016). Post-1970s production increases were facilitated by legal and illegal antibiotic use. Although China's Ministry of 
Agriculture introduced withdrawal times and banned medically relevant feed additives in 1989, regulations were ignored. According to a 1997 report, 750-1000 tonnes of chlortetracycline and 5000-7000 tonnes of oxytetracycline were annually fed ca. 500 million pigs, 36 million cattle, and 70 billion poultry. In 1996, ca. 43,000 tonnes of mycelia wastes were also fed to animals (Shaohong, 1997; Milanov et al., 2016). By 2010, China had become the world's largest consumer of agricultural antibiotics (ca. 23\% of global use) (Van Boeckel et al., 2015).

With 1970s AGP restrictions barely making a difference in West Europe or elsewhere, global antibiotic use continued to increase. A significant part of this increase was caused by the adoption of antibiotic intensive production in new countries and livestock sectors. However, the increase was also caused by a growing cycle of antibiotic dependency within already intensified areas of production. On both sides of the Iron Curtain, policymakers were not only unwilling to challenge developmentalist narratives of cheap meat but also found themselves powerless to reign in the antibiotic ghosts they had summoned: in the capitalist 'West', FDA officials failed to ban AGPs against sustained agro-industrial opposition while European regulators proved unable to control black markets and rethink their own policies. In the non-capitalist 'East', officials were caught in a dilemma of having to provide sufficient antibiotics to maintain inefficient livestock facilities and the need to combat drug residues and AMR. While widening access to cheap meat may be interpreted as a public benefit, the main financial beneficiaries of rising antibiotic use were the companies producing and selling animals, veterinary products, and medicated feeds on an increasingly global scale. The early dominance of US and European corporations is now, however, being challenged by companies from the middle-income countries Western corporations were once invited to.

\section{From European to global reform}

The effects of rising antibiotic use on global AMR were predictable. With antibiotic research stalling, 1980s experts renewed warnings of an imminent post-antibiotic era. In Western countries, bestsellers like Orville Shell's Modern Meat (Schell, 1985), Jeremy Rifkin's Beyond Beef (Rifkin, 1992), or Stuart Levy's Antibiotic Paradox (Levy, 1992) led to fierce finger-pointing between medical, veterinary, and agricultural practitioners. Although public debates initially had little impact on policymaking among major antibiotic consumers, they led to significant reforms in Scandinavia.

Historically, the efficacy requirements of the 'Nordic Welfare State' had made Scandinavian countries very conservative when it came to antibiotic use in medicine (Lie, 2014). However, medical conservatism had not prevented rising antibiotic use in agri- and aquaculture. This changed during the 1980s. In Sweden, Swann-style AGP restrictions had been introduced in 1977. However, in 1981, newspaper articles and the influential children's book author Astrid Lindgren began calling for further bans. In contrast to other countries, Swedish farmers reacted proactively and tried to improve their image by petitioning for a total AGP ban. Parliament reacted by banning all AGPs from 1986 onwards. Struggling to adapt production systems, some farmers, however, replaced AGPs with higherdosed prophylactics. In 1987, public criticism of Swedish animal husbandry's ongoing antibiotic-dependency was one of the factors leading to the passage of a comprehensive new animal welfare law designed to reform industry. Prime Minister Ingvar Carlson personally drove to Lindgren's house to inform her of the so-called Lex Lindgren, which among other things mandated greater space requirements, increased weaning ages, and new straw and litter requirements for pigs (Wierup, 2001; Andersen, 2018; Kahn, 2016).

Other Scandinavian countries also reformed antibiotic use and rearing systems. In Norway, AMR concerns led to a review of antibiotics in aquaculture. While nearly 50 tonnes of antibacterial substances were used in Norwegian aquaculture in 1987, preventive measures like vaccines helped reduce consumption to below five tonnes in 1993 (Anon., 2016). Denmark also underwent a radical restructuring of non-human antibiotic use. Since the nineteenth century, Danish farmers had supplied global markets with pork and bacon. Organised in large integrated cooperatives, farmers had also adopted confined production systems and routine antibiotic use. Following similar detections in Germany and Britain, Danish microbiologists reported the isolation of vancomycin resistant enterococci (VRE) from healthy pigs and poultry in 1993. VRE detections were likely due to the extensive use of avoparcin. While ca. $22 \mathrm{~kg}$ of the reserve antibiotic vancomycin had been used to treat humans in Denmark in 1993, 19,472 kg of closely related avoparcin had been used as AGPs (Aarestrup, 1995). Following heated debates, farmers stopped using avoparcin voluntarily and Denmark banned avoparcin in 1995. Although it resulted in a temporary rise of therapeutic antibiotic use, Danish AGP consumption plummeted from $115,786 \mathrm{~kg}$ in 1994 to $12,283 \mathrm{~kg}$ in 1999 when producers voluntarily phased out AGPs altogether (Aarestrup et al., 2001; Kahn, 2016).

Scandinavian countries also lobbied for wider EU restrictions. In 1995, Denmark, the Netherlands, and Germany opposed a British request to license avoparcin for dairy cows. ${ }^{29}$ A 1996 German avoparcin ban was followed by an EU-wide ban in 1997. Scandinavian pressure soon led to further restrictions. Concerned about having to abandon its stricter laws to comply with more permissive EU feed regulations after its 1995 accession, Sweden campaigned for wider AGP bans. The Swedish campaign profited from Britain's mad cow disease (BSE) crisis and won the support of EU consumer organisations and medical experts. Ignoring industry protest and the EU's Scientific Committee on Animal Nutrition (SCAN), member states banned four popular AGPs and established the European Antibiotic Resistance Surveillance System (EARSS) in 1998. Although a planned phase-out of coccidiostats was abandoned in 2003, the EU restricted remaining AGPs by 2006 (Kirchhelle, 2016; Kahn, 2016). Two years earlier, residue detections in honey had also led to a ban of routine streptomycin spraying against fire blight (Bundestag, 2008; Mayerhofer et al., 2009). Although European farmers retained access to higher-dosed therapeutic and prophylactic antibiotics via veterinary prescriptions and emergency spraying permits, the EU's precautionary bans marked a significant victory for antibiotic critics. The EU's perceived leadership and large protected market also placed significant pressure on other countries to reform-or at least to appear to reform-agricultural antibiotic use.

In the US, antibiotic reforms proved difficult. After failing to overcome industrial resistance to bans, FDA officials had stopped pushing for AGP restrictions and were battling allegations of inadequate enforcement following sulfamethazine detections in milk and reports of widespread noncompliance with existing antibiotic regulations on farms. The mood in Washington also dampened hopes for AMR-oriented reform. During the 1990s, Congress shortened FDA licensing periods and facilitated extralabel drug use in animal feeds. Under conflicting pressure to respond to rising $A M R$ and reduce alleged market barriers, the FDA's dilemma was particularly pronounced in the case of agricultural fluoroquinolone use. In 1995, FDA officials licensed two fluoroquinolone antibiotics for use in poultry feeds and water despite warnings about the drugs' close relation to human reserve 
antibiotics. Officials reassured critics that AMR detections would lead to quick withdrawals. This promise proved difficult to keep. In 1997, the FDA reacted hesitantly to AMR reports by banning extra-label applications. After this measure proved toothless, officials launched formal withdrawal procedures in 2000. However, Bayer, the manufacturer of one of the fluoroquinolones (Baytril/enrofloxacin), resisted in court. Although Baytril's similarity to Bayer's reserve antibiotic ciprofloxacin became a national security matter in the wake of the 2001 anthrax letters, it took the FDA until 2005 to formally withdraw the drug (Kahn, 2016; Kirchhelle, 2019).

Concerned about their ability to ban substances, FDA officials also reacted hesitantly to contemporary EU AGP restrictions. Despite several Congressional initiatives for statutory restrictions of medically relevant antibiotics, the agency focused on developing voluntary guidances to phase out antibiotic growth promotion via label changes (Kirchhelle, 2019). Although US agricultural antibiotic use has recently declined (FDA, 2017), it remains to be seen whether reductions are due to voluntary FDA guidances or to shifting consumer demand and growing doubt about AGPs' economic efficacy. Meanwhile, therapeutic and prophylactic antibiotic use in animal and plant production remain legal. ${ }^{30}$

Regulatory change has also occurred in other high-income countries. In Japan, regulators reacted to EU reforms by banning avoparcin and orienticin feed additives in 1997. Residue problems in domestic and imported produce also led to a reduction of antibiotic tolerances (Morita, 1997). Although Japan continues to allow multiple AGPs, agricultural antibiotic consumption declined from ca. 1060 to 781 tonnes between 2000 and 2013. Japan has recently announced that it will cut overall antibiotic use by another third by 2020 ((Milanov et al., 2016; JVARM, 2013; Anon., 2017). In South Korea, AMR detections in 18 major food items sparked major public concern during the 2000s. Following 2005, over 45 antimicrobial feed additives were restricted to veterinary prescription. Although it remains high, antibiotic consumption declined from over 1500 to under 1000 tonnes between 2007 and $2016 .^{31}$

Middle- and low-income countries have similarly endorsed antibiotic reform. The $2015 \mathrm{mcr}-1$ episode triggered colistin bans in Brazil and China (Walsh and Wu, 2017; Davies and Walsh, 2018). In 2016, Vietnam announced that it would reduce the number of feed antibiotics to 15 and ban AGPs by 2020 (USDA, 2016). India has similarly developed an action plan for antibiotic reductions and has introduced drug withdrawal times for livestock production (Kahn, 2016). According to a 1997 report, Russian antibiotic consumption and AMR rates in farm-related organisms declined 1.5-3-fold following the collapse of the USSR. Only non-medical growth promoters like bacitracin, grisin, flavomycin, and virginiamycin remained permitted (Panin et al., 1997). Russia is also backing FAO-led efforts to promote food safety and prevent AMR in Central Asia and Eastern Europe (FAO, 2017). In reaction to new WHO initiatives, Bangladesh, Bhutan, Indonesia, Myanmar, Nepal, Sri Lanka, and Thailand have similarly announced agricultural antibiotic restrictions and national action plans (Goutard, 2017).

\section{Through the looking glass}

The international wave of antibiotic stewardship commitments is commendable. However, a closer look often reveals an historically familiar lack of enthusiasm when it comes to enforcing regulations or supporting further reform.

Wealthy countries like Korea, Japan, the US, and EU member states have managed to stall decades of increasing antibiotic use and establish surveillance systems with which to hold policymakers accountable to stewardship commitments. However, significant differences of antibiotic regulation and consumption remain. Even within the EU, countries like Spain and Italy consume significantly more drugs than Northern members (EMA, 2017). Many countries have restricted medically relevant AGPs but have not reformed prescribed access to higher-dosed antibiotics. Despite recent reductions, antibiotic use in most highincome countries remains significantly higher than during the 1960s when agricultural AMR selection first caused international alarm (Kirchhelle, 2018).

In the absence of long-term funding commitments and international controls, antibiotic stewardship also remains patchy in middle- and low-income countries. A 2017 review of the WHO's South East Asia Region (SEAR) found that many SEAR states did not enforce regulations or monitor antibiotic use in agri- and aquaculture (Goutard, 2017). In Russia, the past 18 years have seen a sharp rise in agricultural antibiotic use and imports. Although authorities are trying to curb residues in food, AMRoriented regulations have not made an impact (Witte, 1998; Van Boeckel et al., 2015; Vorotnikov, 2016). In China, domestic colistin bans have resulted in the export of thousands of tonnes of domestically produced colistin to India, Vietnam, and South Korea. In 2017, at least five Indian pharmaceutical companies openly advertised colistin growth promoters or metaphylactic applications (Davies and Walsh, 2018).

With the global regulatory landscape still resembling a patchwork, industry itself has emerged as an ambivalent force for antibiotic stewardship. Reacting to shifting consumer preferences and doubts about AGP efficacy, international corporations like McDonalds are offering 'antibiotic free' products. Other major fast food chains, supermarkets, and suppliers have also committed to reducing antibiotic use (Kirchhelle, 2019). Historically, the integration of feed, animal, and food companies was a force for intensification and antibiotic use. Established international supply chains could now, however, function as a force for quick antibiotic reductions. The question is whether incentives for meaningful change are strong enough. So far, industry's record is mixed as recently evidenced in India where one of McDonalds' major suppliers imported colistin growth promoters (Davies and Walsh, 2018). 'Antibiotic free' also does not mean that drugs were never used therapeutically or prophylactically during production. In the absence of statutory bans, there is moreover no guarantee that companies will not reintroduce antibiotics in the future. Historically, this has occurred in both the UK and the US (Kirchhelle, 2019). Perhaps most importantly, companies have little incentive to rethink antibiotic use holistically. Producing 'antibiotic free' products for wealthy consumers is one thing, committing to open-ended reductions of total antibiotic use is another thing. The ongoing rise of global drug consumption indicates that antibiotics remain an accepted industrial go-to for the management of microbial populations.

Although most nation states' stewardship record is certainly not impressive, industry thus remains an unlikely leader of longterm antibiotic reform. Similar to the history of pesticide regulation (Mart, 2015), relying on the market-driven provision of 'antibiotic free meat' not only risks the creation of very unequal access to allegedly safe food. What is more, it also runs danger of reinforcing regulatory stagnation by rhetorically displacing responsibility for what can only be tackled at the societal and political level onto the shoulders of individuals. This is not to say that consumer action and industry reform are not important when it comes to creating more sustainable, safe, and antibioticfree forms of food production. Historically, the alignment of consumer pressure for 'pure' milk and improved animal welfare led to successful reforms at the national and transnational level. However, for change to become permanent and burdens to be 
distributed in a just way, agricultural reform requires long-term institutionalisation in the form of nuanced statutory intervention at the nation state and international level.

\section{Epilogue: a history of failure}

So, what can an historical perspective bring to current debates? At first glance, the message of this paper is grim: over the last 83 years, the global story of sulpha drug, antibiotic, and AMR regulations has been one of failure or stagnation.

Probably the most important reason for this story of failure is that many countries have historically favoured reliable access to cheap meat over broader agricultural and antibiotic reform. Despite popular attacks on 'Big $\mathrm{Ag}$ ' for spreading antibioticdependent production, the global history of agricultural antibiotics was initially one of immediate economic and political pressures as well as of ideological promises of plenty. Reacting to genuine agricultural demand and concerned about reducing imports, freeing agricultural labour, preventing communism, or sating the appetites of restive citizens, capitalist and communist planners alike licensed one antibiotic application after another. With the exception of early bans on antibiotic preservatives and residues in milk, the fiat of widening access to cheap food outweighed early warnings about antibiotic hazards. By around 1970, antibiotic infrastructures had become firmly entrenched in 'Western' and 'Eastern' food production. Once a system had become culturally and materially reliant on routine antibiotic use, further production increases were usually accompanied by rising drug use. Over time, the shared productivist ideal of the farm as factory led to a remarkably similar development of agricultural systems on both sides of the Iron Curtain: more food was produced with less feed, labour, and space but with more external pharmaceutical inputs. Even after the fall of the USSR, this logic of industrialised intensive production is still gathering pace and transforming agriculture in low- and medium income countries.

The second reason for failure is that antibiotics' perceived importance within global protein production repeatedly narrowed the scope of reforms. In the Soviet sphere and the US, officials mostly focussed on curbing residues in food and milk but not antibiotic consumption per se. Although European countries pioneered precautionary AGP restrictions, decision-makers ignored calls for a revaluation of overall antibiotic dependencies. With the exception of Sweden, the ongoing availability of nontherapeutic AGPs, coccidiostats, and higher-dosed prescriptions minimised early bans' impact on European agriculture until the 2000s. Meanwhile, the kaleidoscopic nature of international antibiotic regulations repeatedly served as a useful argument against more ambitious reforms. Why should national farmers be put at a disadvantage if their competitors retained freer access to antibiotics? Despite the recent international wave of wider AGP restrictions and voluntary antibiotic reductions by industry, higher-dosed forms of antibiotic use have not been reviewed systematically and global antibiotic consumption and AMR continue to rise.

Stories of failure are bleak but can hold important lessons for current regulators. One of the most crucial ones is that national regulations have limited impacts. Historically, the international patchwork of regulations has been a major obstacle for effective antibiotic stewardship. Since the 1950s, the capitalist and noncapitalist supply chains driving antibiotic production and consumption have been international. Regulating these supply chains and reducing antibiotic consumption will require global solutions that are mid- to long-term, flexible, and are subject to transparent evaluation. It is one thing for a government to sign international accords but a very different thing to enact concrete and verifiable antibiotic reductions. Recent WHO plans for global AMR and antibiotic surveillance are an important step but require global enactment as well as consistent funding by wealthier nations (WHO, 2017). However, from an historical perspective, even these measures will only go so far. Without challenging the ideals of factory-like production and cheap protein that are still driving antibiotic use, current reforms will have limited success.

Received: 8 April 2018 Accepted: 10 July 2018

Published online: 07 August 2018

\section{Notes}

1 The Veterinary Record had reported on Prontosil since 1935 (Vet Rec (1935) Vol. 15, 1305) but had cautioned veterinarians to await trials on various pets and farm animals before using it (Vet Rec (1936) Vol. 48, 971; (1938) Vol. 50, 1012-1013; 1203-1213). In 1938, pharmaceutical manufacturers like Wellcome, Bayer, and May \& Baker began to display sulphonamide products at veterinary fairs (Vet Rec (1938) Vol. 50, 1340-1344;). Sulpha adverts appeared in the veterinary press from 1939 onwards (Vet Rec (01.04.1939, xiii; 25.11.1939, vi.; 23.03.1940, viii; 27.07.1940, iv).

2 There has been confusion about an alleged 1954 Dutch AGP ban due to an erroneous statement in Finlay and Marcus, 2016. 'Consumerist Terrorists': Battles over Agricultural Antibiotics in the United States and Western Europe. Agricultural History, 90, 146-172.; Mathijs Witte has reconstructed the two-step Dutch licensing of AGPs in 1954 for chickens and in 1955 for piglets Witte, 2012. Aanzet tot een geschiedenis van antibiotica als veevoederaadditief in de varkesnshouderij in Nederland 1950-1970. Argos 46, 190-199.

3 For France, see ongoing work by Delphine Berdah.

4 Licences were granted for bacitracin (1960), streptomycin-penicillin combinations (1962), and tylosin, spiramycin, and oleandomycin (1969).

5 See also: WM MacKay, 'Discussion', Vet Rec. (1953) Vol. 65, 845; ongoing work by Alex Bowmer and Delphine Berdah.

6 The National Archives (in the following TNA) FO 371/106274 Hungarian Press Summary No. 83 (10.04.1953); FO 371/106405 Economic Report No. 9 - Poland (01 -31.12.1952); FO 371/111490 Hungarian Press Summary (25.05.1954); FO 371/ 112658 Penicillin production-Belgrade (16.10.1954); FO 371/151309 Sino-Soviet Bloc Economic Activities in the Middle-East, Asia, Africa, and Latin America, midJanuary-mid-February Appendix B, 1; FO 371/128456 min Sino-Czechoslovak Relations (11.03.1957), 2.

7 TNA FO 371/143559 Report of the East-West Exchange Programme (31.12.1958), 12 \& 27; FO 371/143559 Agreement Between the USSR and the USA on Cooperation in the Scientific, Technical, Educational and Cultural Fields in 1960-1961.

8 TNA FO 371/111659 British Legation Bucharest, Medicine in the Rumanian People's Republic (18.02.1954), 4; FO 371/128955 British Legation Bucharest to Brimelow (16.05.1957), 2; FO 371/106406 British Embassy Warsaw to Hohler (21.01.1953).

9 TNA FO 371/116380 Clemens to Whitworth (18.01.1955).

10 See ongoing research by Dmitriy Myelnikov for allegations of Soviet tetracycline theft; TNA FO 371/116308 Press Summary Bulgarian news 31.07./01.08.1955); FO 371/135216 Wilton to Joy (29.09.1958); FO 371/128834-1957 Poland increases terramycin and aureomycin production; FO 371/122429 Hungarian Press Summary No. 36; Szabad NEP No. 42 (11.02.1956); FO 371/134813 Announcement Central Department on Results of the Fulfilment of the State Plan for the Development of the National Economy During the First Quarter of 1958 (25.04.1958).

11 TNA FO 371/116842 Report of the Delegation to the Agricultural Exhibition, Moscow August 1955, 35.

12 TNA FO 371/151776 Replies to questions 'Zegednienia Weterialy' No. 13 (July 1960), VI; FO 371/135397 Meetings of International Institute of Refrigeration, Moscow, 1958.

13 Polyanskiy Report-Pravda (23.12.1959), Foreign Broadcast Information Service Daily Reports (06.01.1960), 16.

14 TNA FO 371/142917 Summary of Principal Events in Bulgaria (16.-31.10.1959); TNA FO 371/135216 Wilton to Joy (29.09.1958); FO 371/142717 Despatch No. 19ES British Embassy Prague (20.02.1959); FO 371/134813 Directives of the 7th Congress of the Bulgarian Communist Party for the Third Five Year Plan 1958-1962 (12.06.1958); see also: Gomulka Speech In Poznan. Warsaw Polish Home Service (09.04.1961), Foreign Broadcast Information Service Daily Reports (10.04.1961), 8; Congress Resolution of the 12th Congress of the Czechoslovak Communist Party on the main direction of the further development of socialist society, 10.12.1962, Foreign Broadcast Information Service Daily Reports (23.01.1963), 9.

15 TNA FO 371/109502 Tensions Within the Soviet Captive Countries (Legislative Reference Service of the Library of Congress, 28.07.1953); see also similar reports from Romania and Albania FO 371/106490 Haunworth to Hohler (25.08.1953); FO 371/107287 Albania Log No. II Feb 1953, 7. 
16 US National Archives and Records Administration (in the following: NARA) RG 88, Folder 432.1 June-Dec, Box 3040, GS, DF A1/Entry 5, Antonio Santos Ocampo, Jr. to GV Peacock, Aug 30, 1961, enclosed in: Robens to Ocampo, Jr., Oct 2, 1961.

17 Personal Correspondence with Sanofi Business Archivist Stefan Dinges (10.11. 2017).

18 Data on non-medicinal use does not include therapeutic antibiotic applications on farms or sulphonamide consumption.

19 'Khrushchev sees Iowa agriculture', Wallaces Farmer, 03.10.1959, 8

20 New Method Of Food Preservation', Times, 11.04.1956, 13.

21 They had never looked for residues in the first place.

22 TNA FD1/8226 ((ARC/MRC Joint Committee on Antibiotics, Scient. SubCommittee. Antibiotic for Animal Feeding Use only, Suggestion by Bayer Products Ltd., [undated]).

23 Bayerisches Hauptstaatsarchiv HSTA MELF-173 c 7132/1676 Bundesminister für Ernährung, Landwirtschaft und Forsten (BMELF) Sitzung der Referenten für Futtermittelwirtschaft 5/6.10.1977 (25.10.1977), 5; 7132/1662 BMELF Sitzung der Referenten für Futtermittelwirtschaft 15/16.05.1977, 5; 7132/1677 BMELF an die Minister und Senatoren für ELF (10.11.1977) - Anlage 2 -Institut für Veterinärmedizin (15.09.1976)

24 Japan, Canada, the US, and Chile emerged as other aquaculture hotspots.

25 In France, the synthetic fluoroquinolone flumequin was licensed as 'Fire Stop'. German farmers experimented with nourseothricin.

26 Licensed GDR AGPs included penicillin, chlortetracycline, oxytetracycline, zinc bacitracin, flavomycin, virginiamycin, and tylosin. Before the introduction of nourseothricin, oxytetracycline, and zinc bacitracin (since 1977) in broiler rations had been mandatory (Jeroch 1978, p. 657)

27 During the 1970s, improved East-West relations led to liberalised EEC import quotas for communist countries. Meanwhile, West Germany's non-recognition of GDR sovereignty meant that the GDR was a 'silent member' of the EEC market Van Ham, 2016. The EC, Eastern Europe and European Unity: Discord, Collaboration and Integration Since 1947, London et al., Bloombury Publishing.

28 Five-day withdrawal rules for drugs to clear animals' system prior to slaughter had been introduced in the socialist bloc in 1973 .

29 Avoparcin was temporarily licensed as a feed additive for non-lactating dairy cattle between 1996 and 1997; Hansard-House of Commons Daily Debates, 18.03.1997, Col. 560.

30 In 2009 , the US used $16,465 \mathrm{~kg}$ of antibiotics to protect plants. Canada, Mexico, Israel, and New Zealand also permit routine antibiotic plant protection; Stockwell and Duffy, 2012. Use of antibiotics in plant agriculture. Revue scientifique et technique International de L'Office International des Epizooties, 31, 199-210.

31 FAO Presentation Jang Won Yoon and Suk-Kyung Lim, 'Korea's experience of total ban of antibiotics in animal feed' (27.11.2017); URL: http://www.fao.org/fao-whocodexalimentarius/sh-proxy/en/?lnk=1\&url=https\%253A\%252F\%252Fworkspace. fao.org\%252Fsites\%252Fcodex\%252FMeetings\%252FCX-804-05\%252FSIDE\% 20EVENTS\%252FRepublic_of_Korea.pdf

\section{References}

Aarestrup FM (1995) Occurrence of glycopeptide resistance among Enterococcus faecium Isolates from conventional and ecological poultry farms Microbial Drug Resistance 1(3):255-257

Aarestrup FM, Seyfarth AM, Emborg H-D, Pedersen K, Hendriksen R, Bager F (2001) Effect of abolishment of the use of antimicrobial agents for growth promotion on occurence of antimicrobial resistance in fecal enterococci from food animals in Denmark. Antimicrob Agents Chemother 45:2054-2059

Andersen J (2018) Astrid lindgren: The woman behind pippi longstocking. Yale University Press, New Haven

Anon (1959) South African Veterinary Medical Association-Proceedings 53rd Annual Congress. J South Afircan Vet Med Assoc 30:57-59

Anon (1981) Jahrestagung der Gesellschaft für Ernährung in der DDR, Sektion Tierernährung. Arch Anim Nutr 31:221-264

Anon (1985) Committee on government operations-Human Food Safety and the Regulation of Animal Drugs. Union Calendar Washington House of Representatives. Washington DC - the Union Calendar

Anon (2016) Use of antibiotics in Norwegian aquaculture on behalf of Norwegian Seafood Council. Norwegian Veterinary Institute, Oslo

Anon (2017) Nippon AMR One Health Report (NAOR). AMR ONE Health Surveillance Committee, Tokyo

Backhaus GF, Klingauf F (1998) Die feuerbrandkrankheit und ihre bekämpfung in der bundesrepublik Deutschland. Nachr Des Dtsch Pflanzenschutzd 50:193-199

Bakker SK, Davies PVA (1972) Journal of the South African Vetermariny Medicine Association. A Represent Surv Pig Ind Repub South Afr 43:132-140

Begemann S, Perkins E, Van hoyweghen I, Christley R, Watkins F (2018) How political cultures produce different antibiotic policies in agriculture: A historical comparative case study between the UK and Sweden. Sociologia Ruralis. https://doi.org/10.1111/soru.12206

Belasco WJ (2007) Appetite for change. How the counterculture took on the food industry. Cornell University Press, Ithaca and New York
Black KD (2008) Environmental aspects of aquaculture. In: Culver K and Castle D (eds.) Aquaculture, Innovation and Social Transformation, pp 97-114. Dordrecht: Springer

Braude R (1978) Antibiotics in Animal Feeds in Great Britain. J Anim Sci 46:1425-1436

Bud R (2009) Penicillin: Triumph and tragedy. Oxford University Press, Oxford

Bundestag (1990) Drucksache 11/7770-Unterrichtung der gesetzgebenden Körperschaften gemäß Artikel 2 des Gesetzes zu den Gründungsverträgen der Europäischen Gemeinschaften. Drucksache 11/7770

Bundestag (2008) Drucksache 16/9929-Antwort der Bundesregierung auf die Kleine Anfrage der Abegordneten Dr. Cristel Happach-Kasan, Birgit Homburger, Hans-Michael Goldmann, weiterer Abegeordneter und der Fraktion der FDP: Gefährdung des Obstanbaus durch den Feuerbranderreger in Deutschland

Burns M (2005) The development of penicillin In the Netherlands 1940-1950: The pivotal role Of NV Netherlandsche gist- en spiritusfabriek. $\mathrm{PhD}$, University of Sheffield, Delft

Burns M (2011) Wartime research to post-war production: Bacinol, Dutch Penicillin, 1940-1950. In: Romero A, Gradmann C, Santemases M (eds): Circulation of Antibiotics: Journeys of Drug Standards. Madrid and Oslo (= ESF Networking program Drugs, Preprint No. 1):37-59

Campbell WC (2008) History of the discovery of sulfaquinoxaline as a coccidiostat. J Parasitol 94:934-945

Capocci M (2014) Cold drugs, circulation, production and intelligence of antibiotics in post-WWII years. Med Nei Secol- Arte E Sci 26:401-422

Capone DG, Weston DP, Miller V, Shoemaker C (1996) Antibacterial residues in marine sediments and invertebrates following chemotherapy in aquaculture Aquaculture 145:55-75

Castanon JIR (2007) History of the use of antibiotic as growth promoters in European poultry feeds. Poult Sci 86:2466-2471

Chandler CIR, Hutchinson E, Hutchison C (2016) Addressing antimicrobial resistance through social theory. An anthropologically oriented report London School of Hygiene \& Tropical Medicine, London

Conford P, Holden P (2011) The soil association. In: L W (Ed.) Organic farming An international history. CABI, Wallingford and Cambridge (M.A.), pp $187-200$

Cozzoli D (2014) Penicillin and the European response to post-war American hegemony: the case of Leo-penicillin. Hist Technol 30:83-103

Cullather N (2010) The hungry world. America's cold war battle against poverty in Asia. Harvard University Press, Cambridge (Ma.) and London

Culver K, Castle D (2008) Editors' introduction. In: Culver K (Ed.) Aquaculture, innovation and social transformation. Springer, Dordrecht, pp 1-20

Davies M, Walsh TR (2018) A colistin crisis in India. Lancet Infect Dis 18:256-257

Dyer I, O’Mary C (1977) The Feedlot. Lea \& Febinger, Philadelphia

Eagar H, Naidoo V (2017) Veterinary antimicrobial stewardship in south Africa. Int Biol Rev 1:1-14

Eagar H, Swan G, Van vuuren M (2012) Survey of antimicrobial usage in animals in South Africa with specific reference to food animals. J South Afr Vet Med Assoc 83:1-8

EMA (2017) Sales of veterinary antimicrobial agents in 30 European countries in 2015. Trends from 2010 to 2015. EMA, Brussels

Etienne J, Chirico S, Gunabalsingham T, Dautzenberg S, Gysen S (2017) EU Insights-Perceptions on the human health impact of antimicrobial resistance (AMR) and antibiotics use in animals across the EU. EFSA supporting publication: EN-1183

FAO (2016) The FAO action plan on antimicrobial resistance 2016-2020. FAO, Rome

FAO (2017) Russia backs FAO work to tackle antimicrobial resistance with $\$ 3.3$ million

FDA (2017) 2016-Summary report on antimicrobials sold or distributed for use in food-producing animals. FDA, Washington

Finlay MR (2004) Hogs, antibiotics, and the industrial environments of postwar agriculture. In: Scranton P, Schrepfer SR (eds) Industrializing organisms. Introducing evolutionary history. Routledge, London, pp 237-260

Finlay MR, Marcus AI (2016) 'Consumerist Terrorists': Battles over agricultural antibiotics in the United States and Western Europe. Agric Hist 90:146-172

Fitzgerald D (2003) Every farm a factory. The industrial ideal in American agriculture. Yale University Press, New Haven and London

François MAC (1966) L'utilisation des antibiotiques en alimentation animale. Bull De l'Académie Natl De médicine 150:14-23

Fukuoka M (1985) Natural farming. Japan Publications, New York and Tokyo

G20 (2017) Berlin declaration of the G20 health ministers. G20, Berlin

Gause GF (1955) Recent studies on albomycin. A new antibiotic. Br Med J 2:1177-1179

Godley A, Williams B (2009) Democratizing luxury and the contentious 'invention of the technological chicken' in Britain. Bus Hist Rev 83:267-290

Goutard F (2017) Antimicrobial policy interventions in food animal production in South East Asia. BMJ 358:36-41 
Hausmann H-J (2012) Eine Anekdote. Dtsch Ärzteblatt 109:539

Henton MM, Eagar HA, Swan GE, Vuuren MV (2011) Antibioitc managementa nd resistance in livestock production. South Afr Med J 101:583-586

Hockenhull J, Turner AE, Reyher KK, Barrett DC, Jones L, Hinchliffe S, Buller HJ (2017) Antimicrobial use in food-producing animals: a rapid evidence assessment of stakeholder practices and beliefs. Vet Rec 181(19):510

Hummel R, Tschäpe H, Witte W (1986) Spread of plasmid mediated nourseothricin resistance due to antibiotic use in animal husbandry. J Basic Microbiol 26:461-466

Jeroch H, Abend R, Meixner B, Hennig A, Strauss D, Fleck W (1977) Untersuchungen über den Einfluß von Antibiotikazusätzen auf die Mastleistung der Broiler bei optimaler Ernährung. Arch Anim Nutr 27:195-199

Jeroch H, Meixner B, Mecké R, Hennig A (1978) Untersuchungen über den Einfluß von Antibiotikazusätzen auf die Mastleistung der Broiler bei optimaler Ernährung. Arch Tierernähr 28:657-661

Jeroch H, Prinz M, Hennig A (1974) Untersuchungen über den Einfluß von Antibiotikazusätzen auf die Mastleistung der Broiler bei optimaler Ernährung. Arch für Tierernähr 24:347-354

Jones SD (2003) ValuingAnimals. Veterinarians and their patients in modern America. Johns Hopkins University Press, London and Baltimore

Jukes TH (1985) Some historical notes on chlortetracycline. Rev Infect Dis 7:702-707

JVARM (2013) A report on the Japanese veterinary antimicrobial resistance monitoring system-2008 to 2011. National Veterinary Assay Laboratory/ Ministry of Agriculture, Forestry and Fisheries, Tokyo

Kahn LH (2016) One health and the politics of antimicrobial resistance. Johns Hopkins University Press, Baltimore

Kirchhelle C (2016) Toxic confusion: the dilemma of antibiotic regulation in West German food production (1951-1990). Endeavour 40:114-127

Kirchhelle C (2018) Swann song British antibiotic regulation in livestock production (1953-2006). Bull Hist Med 92:317-350

Kirchhelle C (2019) Pyrrhic progress. Antibiotics in Anglo-American food production 1935-2013. Rutgers University Press, Newark (in press)

Krementsov N (2007) In the shadow of the Bomb: U.S.-Soviet biomedical relations in the early Cold War, 1944-1948. J Cold War Stud 9:41-67

Krüger C (2007) Die Geschichte des Lebensmittelhygienischen Instituts der Veterinärmedizinischen Fakultät der Universität Leipzig. Dissertation Dr. med. vet. (Universität Leipzig), Leipzig

Landecker H (2017) The food of our food: Medicated feed and the industrialisation of metabolism (Keynote, Oxford, Keble College-Oxford Interdisciplinary Microbiome Project Workshop-15 Feb 2017)

Laue A (2017) Dos sozialistische Tier. Auswirkungen der SED Politik auf gesellschaftliche Mensch-Tier Verhältnisse in der DDR (1949-1989). Böhlau Verlag, Köln

Lebek G, Gubelmann P (1979) Sechs Jahre gesetzlich angeordnete Abstinenz von therapeutisch genutzten Antibiotika als nutritive Futterzusätze in der Schweiz -Tierfaeces-Stichproben in einigen landwirtschaftlichen Betrieben. Schweiz Arch für Tierheilkd 121:295-309

Lesch JE (2007) The first miracle drugs. How the sulfa drugs transformed medicine. Oxford University Press, Oxford

Levy S (1992) The antibiotic paradox: How miracle drugs are destroying the miracle. Plenum, New York

Lie AK (2014) Producing standards, producing the nordic region: Antibiotic susceptibility testing, from 1950-1970. Sci Context 27:215-248

Liu YY, Wang Y, Walsh TR, Zhang R, Spencer J, Doi Y, Tian G, Dong B, Huang X, Yu L-F, Gu D, Ren H, Chen X, Lv L, He D, Zhou H, Liang Z, Shen J (2015) Emergence of plasmid-mediated colistin resistance mechanism MCR-1 in animals and human beings in China: a microbiological and molecular biological study Lancet Infect Dis 16:161-168

Manten A (1963) The non-medical use of antibiotics and the risk of causing microbial drug-resistance. Bull World Health Organ 29:387-400

Manten A, Kampelmacher H, Guinée PAM (1962) Frequency of resitance to chloramphenicol and tetracyclines among 13502 salmonella strains isolated in 1961. Antonie Van Leeuwenhoek 28:428-434

Mart M (2015) Pesticides, a Love Story. University Press of Kansas, Lawrence

Mayerhofer G, Schwaiger-nemirova I, Kuhn T, Girsch L, Allerberger F (2009) Detecting streptomycin in apples from orchards treated for fire blight. J Antimicrob Chemother 63:1076-1077

Meara PJ (1959) A survey of penicillin contamination of market milk supplies. S.A. Tydskrif Vir Geneeskunde 821-822 Published on 26 Sep 1959

Milanov D, Ljubojević DB, Čabarkapa IS, Aleksić NŽ (2016) Impact of antibiotics used as growth promoters on bacterial resistance. Food Feed Res 43:83-92

Misato T (1976) The development of agricultural antibotics in Japan. Environ Qual Saf 5:48-55

Misato T, Ko K, Yamaguchi I (1977) Use of antibiotics in agriculture. Adv Appl Microbiol 21:53-83

Morita K (1997) Policies for use of anti-infective drugs in food animal production in Japan. Working papers-Medical impact of antimicrobial use in food animals. WHO, Geneva.
Morris C, Heliwell R, Raman S (2016) Framing the agricultural use of antibiotics and antimicrobial resistance in UK national newspapers and the farming press. J Rural Stud 45:43-53

Müller T (1999) Ein Beitrag zur Geschichte der Krankheiten: Wirtschaftlich bedeutsame Erkrankungen des Rindes in der ehemaligen DDR-Ursachen und Bekämpfung. Dr med vet, Freie Universität Berlin. Dissertation Dr med vet (FU Berlin), Berlin

Munro ALS (1990) Salmon farming. Fish Res 10:151-161

NAS (1980) The effects on human health of subtherapeutic use of antimicrobials in animal feeds. Committee to study the human health effects of subtherapeutic antibiotic use in animal feeds (NRC), Washington DC

Nehring K (1959) Lehrbuch Der Tierernährung und Futtermittelkunde. Neumann Verlag, Radebeul und Berlin

O'Sullivan R (2015) American organic. A cultural history of farming, gardening, shoping, and eating. University of Kansas Press, Kansas

Owens FN, Rios JZ-R, Dubeski PD (1991) Effects of ionophores on metabolism, growth body composition and meat quality. In: Pearson AM, Dutson TR (eds) Growth regulation in farm animals. Elsevier, London and New York, pp 321-342

Panin AN, Violin BV, Kovalev VF (1997) Some problems due to antibiotic resistance and application of feed antibiotics in Russia. Working papers-Medical impact of antimicrobial use in food animals. WHO, Geneva

Perry TW (1980) Beef cattle feeding and nutrition. Academic Press, New York

Podolsky S (2017) Historical perspective on the rise and fall and rise of antibiotics and human weight gain. Ann Intern Med 166:133-138

Poutrus PG (2002) Die erfindung des Goldbroilers. Über den Zusammenhang zwischen Herrschaftssicherung und Konsumentwicklung in der DDR. Böhlau Verlag, Köln

Rifkin J (1992) Beyond beef. The rise and fall of the cattle culture. Penguin Books, London and New York

Ritchie H, Roser M (2018) Meat and seafood production \& consumption. Published online at OurWorldInData.org. Retrieved from: https:// ourworldindata.org/meat-and-seafood-production-consumption

Sample IAN (2013). Antibiotic-resistant diseases pose 'apocalyptic threat', top expert says. Guardian [Online], 23 Jan 2013

Samuelsen OB, Torsvik V, Ervik A (1992) Long-range changes in oxytetracycline concentration and bacterial resistance towards oxytetracycline in a fish farm sediment after medication. Sci Total Environ 114:25-36

Santesmases MJ (2018) The circulation of penicillin in Spain. Health, wealth and authority. Palgrave Macmillan, London

Saraiva T (2016) Fascist pigs. Technoscientific organisms and the history of fascism. MIT Press, Cambridge (MA) and London

Schell O (1985) Modern meat. Antibiotics, hormones and the pharmaceutical farm. Random House, New York

Schönfelder J (2006) Industrielle Tierproduktion bei Neustadt an der Orla (1978-1991). Thüringen Blätter Zur Landeskunde 64 Printed by Landeszentrale für politische Bildung Thüringen

Schramm M (2008) Wirtschaft und Wissenschaft in DDR und BRD. Die Kategorie Vertrauen in Innovationsprozessen. Böhlau Verlag, Köln, Weimar, Wien

Shaohong J (1997) Regulations, realities and reocmmendations on antimicrobial use in food animal productions in China. Working papers-Medical impact of antimicrobial use in food animals. WHO, Geneva

Silbergeld EK (2016) Chickenizing farms \& food. How industrial meat production endangers workers, animals, and consumers. Johns Hopkins University Press, Baltimore

Smith-Howard K (2010) Antibiotics and agricultural change: Purifying milk and protecting health in the postwar era. Agric Hist Soc 84:327-351

Smith-Howard K (2017) Healing animals in an antibiotic age: Veterinary drugs and the professionalism crisis, 1945-1970. Technol Cult 58:722-748

Stock M (2014) Tierschutz in der DDR. Hintergründe zur Entwicklung des Tierschutzes und seiner Organisation. Exemplarische Analyse der Haltungsbedingungen der Tierarten Rind und Schwein unter Tierschutzgesichtspunkten. Dissertation Dr. med. vet. (FU Berlin), Berlin

Stockwell VO, Duffy B (2012) Use of antibiotics in plant agriculture. Rev Sci Et Tech Int De L'Office Int Des Epizoot 31:199-210

Suskind SR (1960) Microbial genetics in the USSR. Q Rev Biol 35:41-79

Swann (1969) Report of the joint committee on the use of antibiotics in animal husbandry and veterinary medicine, 1969-1970. London: HMSO

Tessari A, Godley A (2014) Made in Italy. Made in Britain. Quality, brands and innovation in the European poultry market, 1950-80. Bus Hist 56:1057-1083

Thoms U (2008) Antibiotics in foods: Precarious matters under discussion. In: Balz V, Schwerin AV, Wahrig B (eds) Precarious matters/ prekäre stoffe. The history of dangerous and endangered substances in the 19th and 20th centuries. Max-Planck-Institut für Wissenschaftsgeschichte, Berlin, (preprint) $129-139$

Thoms U (2012) Between promise and threat. antibiotics in foods in west Germany 1950-1980. NTM 20:181-214 
Thoms U (2017) Antibiotika, agrarwirtschaft und politik in Deutschland im 20. und 21. Jahrhundert. Z für Agrargesch und Agrarsoziol 65:35-52

Tiews J (1970) Nutritive anwendung der antibiotika als wirkstoffe in der tierproduktion. Schweiz Arch für Tierheilkd 112:183-202

Tonnessen JN, Johnsen AO (1982) The history of modern whaling. C. Hurst \& Company/ Australian National University Press, London \& Canberra

Tran-Dien A, Le Hello S, Bouchier C, Weill F-X (2017) Early transmissible ampicillin resistance in zoonotic Salmonella enterica serotype Typhimurium in the late 1950s: a retrospective, whole-genome sequencing study. Lancet Infect Dis 18:207-214

USDA (2016) MARD phases out growth promotion usage of antibiotics in feed. USDA - GAIN, Washington

Van Boeckel TP, Brower C, Gilbert M, Grenfell BT, Leven SA, Robinson TP, Teillant A, Laxminarayan R (2015) Global trends in antimicrobial use in food animals. PNAS 112:5649-5654

Van Den Heewer LW, Giesecke WH (1967) The mastitis problem in South Africa -some observations. J South Afircan Vet Med Assoc 38:107-114

Van Ham P (2016) The EC, Eastern Europe and European unity: Discord, Collaboration and Integration Since 1947. Bloombury Publishing, London

VARSS (2017) UK-Veteirnary antibiotic resistance and sales surveillance report. VARSS, New Haw

Vorotnikov V (2016) In-feed antibiotics still used in Russian poultry. Poultry World, 05 Dec 2016

Walsh F (2013) Antibiotics resistance 'as big as terrorism'-medical chief. BBC News [online], 11 Mar 2013

Walsh T, Wu Y (2017) China bans colistin as a feed additive for animals. Lancet Infect Dis 16:1102-1103

Weber W (1962) Vor-und nachteile der antibiotika als futterzusätze bei den verschiedenen haustieren. Schweiz Arch für Tierheilkd 104:340-350

Wesley T (1996) The Japanese animal health market. Animal Pharm Reports/ PJB Publications, London

WHO (2015) Global action plan on antimicrobial resistance. World Health Organisation, Geneva

WHO (2017) Global antimicrobial resistance surveillance system (GLASS) report. Early Implementation 2016-2017. World Health Organisation, Geneva

Wierup M (2001) The Swedish experience of the 1986 year ban of antimicrobial growth promoters, with special reference to animal health, disease prevention, productivity, and usage of antimicrobials. Microb Drug Resist 7:183-190

Williams Smith H (1958) Drug-resistant bacteria in domestic animals [presentation in section of epidemiology and preventive medicine. symposium on epidemiological risks of antibiotics [21.02.1958)]. Proc R Soc Med 51:812-813

Witte M (2012) Aanzet tot een geschiedenis van antibiotica als veevoederaadditief in de varkesnshouderij in Nederland 1950-1970. Argos 46:190-199
Witte W (1998) Medical consequences of antibiotic use in agriculture. Science 279:996-997

Witte W (1999) Medizinische folgen des einsatzes von antibiotika. Dtsch Ärzteblatt 31:A607-A608

Witte W (2000) Selective pressure by antibiotic use in livestock. Int J Antimicrob Agents 16:S19-S24

Woods A (2012) Rethinking the history of modernagriculture: British pig production, c. 1910-65. Twent Century Br Hist 23:165-191

Woods A (2014) Science, disease and dairy production in Britain, c1927-80. Agric Hist Rev 62:294-314

\section{Data availability}

Data sharing not applicable to this article as no datasets were generated or analysed during the current study.

\section{Additional information}

Competing interests: The author declares no competing interests.

Reprints and permission information is available online at http://www.nature.com/ reprints

Publisher's note: Springer Nature remains neutral with regard to jurisdictional claims in published maps and institutional affiliations.

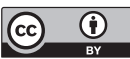

Open Access This article is licensed under a Creative Commons Attribution 4.0 International License, which permits use, sharing, adaptation, distribution and reproduction in any medium or format, as long as you give appropriate credit to the original author(s) and the source, provide a link to the Creative Commons license, and indicate if changes were made. The images or other third party material in this article are included in the article's Creative Commons license, unless indicated otherwise in a credit line to the material. If material is not included in the article's Creative Commons license and your intended use is not permitted by statutory regulation or exceeds the permitted use, you will need to obtain permission directly from the copyright holder. To view a copy of this license, visit http://creativecommons.org/ licenses/by/4.0/

(C) The Author(s) 2018 